\section{Mediaosaaminen ratkaisee menestyksen politiikan kentillä}

Isotalus, Pekka (2017). Mediapoliitikko. Gaudeamus. 247 sivua.

KUMPI HALLITSEE JULKISUUTTA enemmän: poliitikko, joka syöttää medialle haluamansa otsikot, vai toimittaja, joka kirjoittaa poliitikoista haluamansa sisällöt, kysyy puheviestinnän professori ja poliittisen viestinnän dosentti Pekka Isotalus teoksensa Mediapoliitikko esipuheessa. Kolmanneksi ääneksi poliitikon ja toimittajan kanssa kirjassa asettuu äänestäjä-kuluttaja, Isotaluksen termiä käyttääkseni. Näiden kolmen toimijan välinen jännite määrittää pitkälti kirjan teemoja.

Politiikkaa tehdään nykyään erilaisin reunaehdoin kuin aiemmin. Voimallisimmin politiikantekoa on muuttanut medioitumiseksi nimetty ilmiö: media vaikuttaa elämäämme monin, niin perustavin tavoin, että sen kaikkia vaikutuksia on vaikea edes hahmottaa.

\section{MEDIA MÄÄRITTÄÄ TODELLISUUTTA}

Käsityksemme melkein kaikesta oman elämänpiirimme ulkopuolisesta suodattuu median kautta. Siten media määrittää, mikä meille on totta. Ymmärryksemme yhteiskunnasta ja yhteisten asioiden hoidosta eli politiikasta rakentuu lähes yksinomaan median välityksellä.

Lisäksi media vaikuttaa siihen, miten asiat meille näyttäytyvät. Median toimintatapojen kokonai- suutta kutsutaan mediatutkimuksessa medialogiikaksi. Se aiheuttaa muun muassa asioiden henkilöitymistä, stereotypisoitumista ja visualisoitumista. Medialogiikka myös vaikuttaa merkittävästi politiikantekoon ja poliitikkojen käytökseen. Isotalus kertoo esimerkin: Ennen media kertoi siitä, mistä eduskunnan kyselytunnilla keskusteltiin. Nykyään eduskunnan kyselytunnilla keskustellaan siitä, mistä media kertoi.

Kirjoittaja käsittelee ensin medioitumista eri näkökulmista ja avaa sitten sen alakäsitteitä omina alalukuinaan. Otsikoista löytyvät politiikan henkilöityminen ja privatisoituminen, poliitikon viestintäosaaminen, vaalikeskustelut sekä sosiaalisen median ja internetin vaikutus politiikkaan.

\section{POLIITIIKKA HENKILÖITYY JA PRIVATISOITUU}

Politiikan henkilöitymistä Isotalus pohtii kiinnostavasti ja kyseenalaistaen. Poliitikot ovat nykykulttuurin monimediaisella areenalla esillä niin monin tavoin, että tutkimuksen keinoin on vaikea päätellä varmasti mitään siitä, käydäänkö poliittisia keskusteluja todella enemmän henkilöiden kuin puolueiden tai asioiden kautta kuten tutkijat useasti ovat väittäneet. Ja jos käydäänkin, voidaanko todeta,

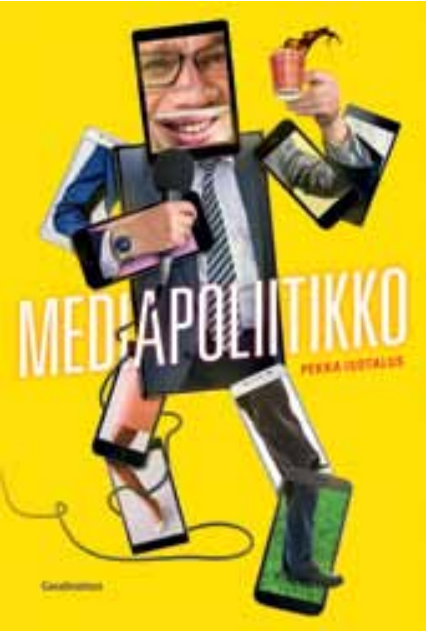

että esimerkiksi vahvat puoluejohtajat eivät silti olisi ennenkin vaikuttaneet äänestäjien päätöksiin voimakkaasti? Tulkinnan vaikeutta lisää median voimakas kuvallistuminen, mikä tuo poliitikkoja henkilöinä esiin aiempaa vahvemmin.

Henkilöitymisen rinnalla teoksessa tarkastellaankin poliitikkojen privatisoitumista eli heidän henkilökohtaisten ominaisuuksiensa ja yksityiselämänsä lisääntynyttä esittämistä julkisuudessa. Ilmiö on kiinnostavan kaksijakoinen: sekä media että poliitikko voivat hyötyä yksityiselämän saamasta palstatilasta, mutta yksityisyyttä on vaikea rajata.

Isotalus ei liitä ilmiötä erityisesti sosiaalisen median nopeaan kasvuun, mutta itse nostaisin sen pääsyyksi poliitikon yksityisen ja julkisen rajan hälvenemiselle. Somessa poliitikko pystyy periaatteessa ohittamaan perinteisen median ja päättämään itse, mitä ja 


\section{PERUSTAVIN TAVOIN.}

miten yksityisyyttään avaa. Somekohut arvaamattomuudessaan ja nopeudessaan ovat kuitenkin yllättäneet monen poliitikon.

Sosiaalisen median osuus kirjassa jää muutenkin ohueksi. Perinteinen media pitää toistaiseksi pintansa poliittisessa viestinnässä, mutta etenkin nuoren yleisön osalta sekä televisio että printtimedia menettävät jatkuvasti merkitystään.

\section{MARGINAALI JÄÄ MARGINAALIIN}

Isotalus sivuaa eri teemoihin liittyen sukupuolen merkitystä mediassa ja politiikassa. Keskustellut aiheet, kuten naispoliitikkojen ulkonäön julkisen kommentoinnin perinne, ovat tärkeitä, mutta kirjoittaja ohittaa ne toteamuksilla, kuten "nykyisin toimittajat osaavat useimmiten välttää näin [mies ärähtää, nainen pillahtaa itkuun] sukupuolittunutta kielenkäyttöä, vaikka toisinaan siihen edelleen törmää”. Räikeäkin heteronormatiivisuus on kuitenkin yhä arkea myös suomalaismediassa, ja sen syyt ovat syvällä yhteiskunnan ja politiikan perinteisissä rakenteissa, mihin olisin suonut kirjoittajan paneutuvan vielä perusteellisemmin. Teoksesta puuttuvat lisäksi politiikan etnisiä ja kulttuurisia vähemmistöjä koskevat huomiot, vaikka media vaikut- taa voimakkaasti vähemmistöjen näkyvyyteen politiikan kentällä. Politiikan ammattimaistuminen, jota kirjassa sivutaan lyhyesti, on omiaan lisäämään epätasa-arvoa politiikan kentillä.

Poliitikon viestintäosaamista koskeva luku käy erinomaisesta perustekstistä kenelle tahansa julkisuudessa esiintyvälle. Ensinnäkin Isotalus käy käytännönläheisesti läpi tarvittavat yksilöviestintätaidot: puhetaidon, mediaosaamisen, viestintäteknologian hallinnan sekä kulttuurien välisen viestinnän ymmärryksen ja kielitaidon. Toiseksi viestintäosaamista tarkastellaan kolmella tasolla: yksilön, ryhmien ja yhteiskunnan kautta. Yksilöviestintä korostuu yleensä viestintäkoulutuksessa, mutta kirjoittajan havainto siitä, että ryhmäviestintä saattaa olla kaikkein keskeisin poliittisen viestinnän taso, on osuva. Samanlaisia tuloksia on esitetty johtamisviestinnän tutkimuksessa.

\section{POLIITIIKAN TUNTEMUS VAHVISTAA DEMOKRATIAA}

Mediapoliitikko rakentuu siten, että jokainen pääteema käsitellään ensin yleisesti, minkä jälkeen kirjoittaja esittää lähikuva-otsikon alla omaa tutkimustaan aiheesta. Esipuheessa Isotalus toteaa, että "kirja osoittaa, että tekemilläni tut- kimuksilla on keskinäisiä yhtymäkohtia ja ne kaikki yhdessä rakentavat tietynlaista kokoavaa näkökulmaa poliitikosta mediassa". Esipuheen virke jää hiukan irralliseksi, kun yleistajuisesta, sinänsä erinomaisesti poliittista viestintää popularisoivasta teoksesta on kyse. Osa lähikuvista toimii hyvin, osa on marginaalisempia, mutta kokonaisuudessaan ne ovat hyvä lisä teoksen sisältöön.

Summa summarum, Isotaluksen teos on ajankohtainen, satunnaisia lyöntivirheitä lukuun ottamatta sujuvasti kirjoitettu ja toimitettu, helposti lähestyttävä sekä rakenteeltaan selkeä ja toimiva. Teos nojaa tieteelliseen tutkimukseen ja avaa poliittisen viestinnän akateemista käsitteistöä ansiokkaasti: termit määritellään ymmärrettävästi ja johdonmukaisesti.

Teosta voi suositella jokaiselle yhteiskunnallisesta päätöksenteosta ja sen kulttuurisista lainalaisuuksista kiinnostuneelle.

Mitä paremmin kansalaiset ovat perillä politiikan toiminnasta ja median sitä ohjaavasta vaikutuksesta, sitä paremmin demokratia toimii.

ANNAMARI HUOVINEN

KTT, viestinnän tutkija Tutkimuskeskus CERS Hanken 